\title{
Poultry byproducts and swine liver used in diets for Nile tilapia juveniles
}

\author{
Kerolay Valadão Carvalho ${ }^{1}$, Thiago Gabriel Luczinski ${ }^{1}$, Wilson Rogério Boscolo ${ }^{1}$ \\ Jakeline Marcela Azambuja de Freitas ${ }^{1}$ \& Altevir Signor ${ }^{1}$ \\ ${ }^{1}$ Center for Engineering and Exact Sciences, State University of Western Paraná, Toledo, Brazil \\ Corresponding author: Kerolay Valadão Carvalho (kerolay.valadao@ hotmail.com)
}

\begin{abstract}
This study aimed at evaluating diets containing protein hydrolysate from poultry byproducts and swine liver (PHPPL), at different inclusion levels, for Nile tilapia (Oreochromis niloticus) juveniles. Seven diets were evaluated, being a negative control (free of both hydrolysate and fishmeal) and positive control (free of hydrolysate but containing fishmeal), besides five diets with 1, 2, 3, 4, or 5\% inclusion of the mixed protein hydrolysate. Significant effects were observed regarding the animals' final length, with higher values with the $1 \%$ inclusion level than the negative control. The liver's quantitative evaluation revealed that inclusions above $3 \%$ might lead to severe alterations in the organ's morphology. The use of PHPPL in the diets that did not contain fishmeal has shown to be effective in maintaining the performance parameters of Nile tilapia. Thus, its use is recommended considering an inclusion level of $3 \%$.
\end{abstract}

Keywords: Oreochromis niloticus; byproducts; protein hydrolysates; fish nutrition; histology; aquaculture

Byproducts derived from animal slaughtering industries are increasingly being used for animal diets, can be included in the diet after being transformed into protein hydrolysates (FAO, 2018). Increased knowledge about the biological effects of protein hydrolysates in aquatic animal's diets of has been increasing in the last decades. However, many gaps remain, especially regarding species with marketing interests. According to Martínez-Alvarez et al. (2015), it is necessary to improve knowledge about the best levels of dietary inclusion of animal byproducts hydrolysates in micro diets and about their biological effects in reared-fish, besides gathering information on the molecular structures of peptide chains of the hydrolysates.

Studies have been carried out to analyze performance parameters in the inclusion of hydrolysates from byproducts of terrestrial animals in fish diets. In a diet offered for Salminus brasiliensis, Lorenz et al. (2018) observed higher weight gain with the inclusion of a swine liver protein hydrolysate (SLH), while Lewandowski et al. (2013) reported an improvement of weight gain, final length, and feed conversion with SLH inclusion in diets for Steindachneridion melanodermatum. In the study of Alves et al. (2019), the authors displayed positive results regarding the use of poultry hydrolysate protein (PHP) and SLH as flavor enhancers for Nile tilapia (Oreochromis niloticus). However, there are no published results about the effects of Nile tilapia's productive performance regarding the inclusion of PHP and SLH in the diets.

The use of protein hydrolysates in diets for Nile tilapia is commercially relevant, seen that this species stands out in the productive aquaculture chain, as the fourth most produced species in the world (FAO, 2018). In this sense, this study aimed to evaluate the effects of the inclusion of blend protein hydrolysates produced with poultry and swine liver byproducts as a feed ingredient for Nile tilapia juveniles zootechnical performance, proximate body composition, and the histological aspect of the liver.

The study was carried at the Laboratory of Aquaculture of the Aquaculture Management Study GroupGEMAq, of the University of West Paraná (UNIOESTE), in Toledo/PR, Brazil. The Ethics Committee on Animal Use approved the study, protocol number 17/19-CEUA of the Paraná Federal University.

Five isoproteic ( $40 \%$ crude protein) and isoenergetic $(3,462 \mathrm{kcal}$ of digestible energy per $\mathrm{kg})$ experimental diets were used, which contained increasing levels of protein hydrolysate of poultry byproducts

Corresponding editor: Jesús Ponce-Palafox 
Table 1. Ingredients used in the experimental diets containing different inclusion levels of PHPPL (protein hydrolysate of poultry by-products and swine liver). ${ }^{1} \mathrm{NC}$ : negative control, ${ }^{2} \mathrm{PC}$ : positive control, ${ }^{3}$ mineral/vitamin supplement (composition: vitamin A, vitamin D3, vitamin E, vitamin K3, vitamin B1, vitamin B2, calcium pantothenate, vitamin B6, vitamin B12, niacin, folic acid, biotin, inositol, iron sulfate, manganese sulfate, zinc sulfate, calcium iodate, sodium selenite, copper sulfate, cobalt carbonate, calcium propionate, antioxidant (BHT), mineral oil, silicon dioxide, propylgalate, citric acid).

\begin{tabular}{|c|c|c|c|c|c|c|c|}
\hline \multirow{2}{*}{$\begin{array}{l}\text { Diet } \\
\text { Ingredient }\end{array}$} & \multicolumn{7}{|c|}{ Treatment $(\%)$} \\
\hline & $\mathrm{NC}^{1}$ & $\mathrm{PC}^{2}$ & $1(\%)$ & $2(\%)$ & $3(\%)$ & $4(\%)$ & $5(\%)$ \\
\hline Cornmeal & 24.65 & 25.73 & 25.08 & 25.50 & 25.93 & 26.35 & 26.78 \\
\hline Soybean protein concentrate & 26.09 & 21.33 & 24.82 & 23.55 & 22.28 & 21.01 & 19.73 \\
\hline Rice grits & 10.00 & 10.00 & 10.00 & 10.00 & 10.00 & 10.00 & 10.00 \\
\hline Poultry viscera meal & 10.00 & 10.00 & 10.00 & 10.00 & 10.00 & 10.00 & 10.00 \\
\hline Feather meal & 6.80 & 6.80 & 6.80 & 6.80 & 6.80 & 6.80 & 6.80 \\
\hline Blood meal & 5.00 & 5.00 & 5.00 & 5.00 & 5.00 & 5.00 & 5.00 \\
\hline Corn bran (gluten $60 \%$ ) & 5.00 & 5.00 & 5.00 & 5.00 & 5.00 & 5.00 & 5.00 \\
\hline Fishmeal $55 \%$ & 0.00 & 5.00 & 0.00 & 0.00 & 0.00 & 0.00 & 0.00 \\
\hline PHPPL & 0.00 & 0.00 & 1.00 & 2.00 & 3.00 & 4.00 & 5.00 \\
\hline Soybean oil & 3.67 & 3.30 & 3.54 & 3.41 & 3.28 & 3.15 & 3.02 \\
\hline Alcohol yeast & 2.00 & 2.00 & 2.00 & 2.00 & 2.00 & 2.00 & 2.00 \\
\hline Wheat gluten & 1.00 & 1.00 & 1.00 & 1.00 & 1.00 & 1.00 & 1.00 \\
\hline Dicalcium phosphate & 1.95 & 1.36 & 1.96 & 1.97 & 1.98 & 1.99 & 2.01 \\
\hline Lime & 0.72 & 0.36 & 0.70 & 0.67 & 0.65 & 0.63 & 0.60 \\
\hline L-lysine $\mathrm{HCl}$ & 0.58 & 0.61 & 0.58 & 0.57 & 0.56 & 0.56 & 0.55 \\
\hline L-threonine & 0.55 & 0.56 & 0.55 & 0.55 & 0.56 & 0.56 & 0.56 \\
\hline Sodium chloride & 0.50 & 0.50 & 0.50 & 0.50 & 0.50 & 0.50 & 0.50 \\
\hline Mineral/vitamin supplement ${ }^{3}$ & 0.60 & 0.60 & 0.60 & 0.60 & 0.60 & 0.60 & 0.60 \\
\hline DL-methionine & 0.40 & 0.38 & 0.40 & 0.39 & 0.39 & 0.38 & 0.38 \\
\hline Vitamin C & 0.20 & 0.20 & 0.20 & 0.20 & 0.20 & 0.20 & 0.20 \\
\hline Choline chloride & 0.15 & 0.15 & 0.15 & 0.15 & 0.15 & 0.15 & 0.15 \\
\hline Antifungal & 0.10 & 0.10 & 0.10 & 0.10 & 0.10 & 0.10 & 0.10 \\
\hline Antioxidant & 0.02 & 0.02 & 0.02 & 0.02 & 0.02 & 0.02 & 0.02 \\
\hline Total & 100 & 100 & 100 & 100 & 100 & 100 & 100 \\
\hline \multicolumn{8}{|l|}{ Nutritional levels (\%) } \\
\hline Starch & 23.89 & 24.56 & 24.15 & 24.42 & 24.69 & 24.95 & 25.22 \\
\hline Digestible protein & 34.45 & 34.13 & 34.41 & 34.36 & 34.32 & 34.27 & 34.23 \\
\hline Lipids & 6.69 & 6.94 & 6.64 & 6.00 & 6.55 & 6.50 & 6.46 \\
\hline Total leucine & 3.41 & 3.40 & 3.41 & 3.40 & 3.39 & 3.38 & 3.37 \\
\hline Total arginine & 2.61 & 2.55 & 2.59 & 2.57 & 2.55 & 2.53 & 2.51 \\
\hline Total lysine & 2.60 & 2.60 & 2.60 & 2.60 & 2.60 & 2.60 & 2.60 \\
\hline Total valine & 2.23 & 2.23 & 2.23 & 2.23 & 2.22 & 2.22 & 2.22 \\
\hline Total threonine & 2.20 & 2.20 & 2.20 & 2.20 & 2.20 & 2.20 & 2.20 \\
\hline Total phenylalanine & 2.05 & 2.00 & 2.04 & 2.02 & 2.01 & 2.00 & 1.98 \\
\hline Total isoleucine & 1.61 & 1.59 & 1.61 & 1.60 & 1.59 & 1.58 & 1.58 \\
\hline Calcium & 1.31 & 1.31 & 1.31 & 1.31 & 1.31 & 1.31 & 1.31 \\
\hline Crude fiber & 1.29 & 1.18 & 1.26 & 1.24 & 1.21 & 1.18 & 1.15 \\
\hline Total histidine & 1.05 & 1.03 & 1.05 & 1.04 & 1.04 & 1.04 & 1.03 \\
\hline Total phosphorus & 1.00 & 1.00 & 1.00 & 1.00 & 1.00 & 1.00 & 1.00 \\
\hline Total methionine & 1.00 & 1.00 & 1.00 & 1.00 & 1.00 & 1.00 & 1.00 \\
\hline Available phosphorus & 0.76 & 0.83 & 0.76 & 0.76 & 0.76 & 0.76 & 0.76 \\
\hline Total tryptophan & 0.43 & 0.41 & 0.43 & 0.43 & 0.43 & 0.42 & 0.42 \\
\hline
\end{tabular}

and swine liver (PHPPL), the product provided by the company BRF Ingredients ${ }^{\circledR}(1,2,3,4$ or $5 \%)$. A positive control diet (containing fishmeal) and a negative control diet (without hydrolysate or fishmeal) were used. The diets were produced according to the recommendations of Furuya (2010) and NRC (2011) (Table 1). Both the PHPPL and the produced diets were submitted to analysis of the dry matter, crude protein, ether extract, mineral matter, and energy, according to the methodology of AOAC (2000) (Table 2).

The diet's macronutrients were milled in a hammertype mill (Moinhos Vieira, model MS 280, Tatuí/SP, Brazil) coupled with a $0.3 \mathrm{~mm}$ mesh. After milling, both the micronutrients and protein hydrolysates were added, mixed for $5 \mathrm{~min}$ in a manual mixer. The obtained blend was extruded (Exteec Máquinas, Ribeirão Preto/ 
Table 2. Proximate composition of the experimental diets. PHPPL: protein hydrolysate of poultry by-products and swine

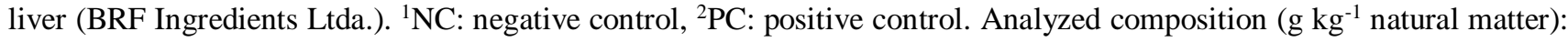
92.20 dry matter; 72.43 crude protein; 6.98 ether extract; 4.62 mineral matter; 4.99 energy. Distribution of molecular weight in Dalton (Da) (\% of peptides: <250 Da: 8.88\%, 250-500 Da: 31\%, 500-1000 Da: 60\%.

\begin{tabular}{lrrrrrrr}
\hline \multirow{2}{*}{ Chemical analyses (\%) } & \multicolumn{7}{c}{ Treatment $(\%)$} \\
\cline { 2 - 8 } & $\mathrm{NC}^{1}$ & \multicolumn{1}{c}{$\mathrm{PC}^{2}$} & $1(\%)$ & $2(\%)$ & $3(\%)$ & $4(\%)$ & $5(\%)$ \\
\hline Dry matter & 93.84 & 93.48 & 90.85 & 92.76 & 94.06 & 93.60 & 92.85 \\
Crude protein & 39.34 & 39.03 & 38.51 & 39.20 & 39.49 & 38.49 & 38.81 \\
Ether extract & 3.45 & 1.73 & 2.80 & 4.43 & 4.43 & 2.86 & 2.71 \\
Mineral matter & 7.56 & 8.44 & 7.55 & 7.49 & 7.77 & 7.62 & 7.53 \\
Energy & 4.37 & 4.29 & 4.41 & 4.37 & 4.43 & 4.40 & 4.42 \\
\hline
\end{tabular}

$\mathrm{SP}$, Brazil) using a $1 \mathrm{~mm}$ matrix at the feed factory of the GEMAq, dried in a forced-ventilation oven $\left(55^{\circ} \mathrm{C}\right)$ for $24 \mathrm{~h}$, packed, identified, and stored in a freezer $\left(-18^{\circ} \mathrm{C}\right)$.

A total of 336 Nile tilapia juveniles [initial mean of $1.42 \pm 0.03 \mathrm{~g}$ standard deviation, SD] were used in this study. Fish were randomly distributed in 28 tanks (70 L), composing seven treatments with four replicates (12 fish per tank), in a water recirculation system, coupled with constant aeration and heating, with a 12:12 (L:D) photoperiod. The animals were fed six times a day (08:00-18:00 with $2 \mathrm{~h}$ intervals) until apparent satiety. Tanks and filters were cleaned daily throughout the experiment, which lasted for 28 days. Water quality parameters were weekly monitored, and the obtained values (mean $\pm \mathrm{SD}$ ) were temperature $30.24 \pm 0.82^{\circ} \mathrm{C}$, pH $6.98 \pm 0.17$, dissolved oxygen $4.33 \pm 1.22 \mathrm{mg} \mathrm{L}^{-1}$, and electrical conductivity $135.0 \pm 9.37 \mu \mathrm{S} \mathrm{cm}^{-1}$, with the aid of a portable probe YSI $556^{\circledR}$. At the end of the experimental period, fish were fasted for $24 \mathrm{~h}$ and euthanized with a eugenol solution (300 $\left.\mathrm{mg} \mathrm{L}^{-1}\right)$. Biometric parameters were acquired (weight and total length), followed by the acquisition of viscera weight.

The productive performance was evaluated by: MIW = mean initial weight $(\mathrm{g}) ; \mathrm{WG}=$ weight gain $(\mathrm{g})$, (mean final weight - mean initial weight); $\mathrm{FL}=$ final length $(\mathrm{cm}) ; \mathrm{SGR}=$ specific growth rate $\left(\% \mathrm{~d}^{-1}\right),[(\mathrm{ln}$ final weight - $\ln$ initial weight) / experimental period]; PER = protein efficiency rate $(\%)$, (weight gain / consumed crude protein $) \times 100 ; \mathrm{AFC}=$ apparent feed conversion (feed consumption / weight gain); SV = survival [(number of fish/12) $\times 100$ ]; and HSI $(\%)=$ hepatosomatic index [liver's weight $(\mathrm{g}) \times 100 /$ final weight $(\mathrm{g})]$

Samples of the liver were processed for histological analysis. These were fixed, dehydrated in increasing alcoholic series, stained using a series of xylol, embedded in paraffin, sectioned $(7 \mu \mathrm{m})$ with the aid of a microtome (Microm, International Gmbh 69190, Walldorf, Germany) and stained with hematoxylin- eosin. Histological slides were evaluated with the aid of an optical microscope P1 BX 50 (Olympus-Manila, Philippines), coupled with a camera (Olympus PMC 35-B, Berlin, Germany). Qualitative analyzes of the liver were performed in six samples per treatment. The qualitative evaluation of hepatic vacuolization was performed according to the criteria established by Caballero et al. (2004). A vacuolization score was attributed, where 0: not observed, 1: few vacuoles, 2 : mean vacuolization, and 3: severe vacuolization (Fig. 1).

The obtained data were submitted to a homogeneity test (Levene), followed by one-way variance analysis (ANOVA) and Tukey's multiple comparison test at a 5\% significance level. All statistical analyses were carried out in the statistical software Statistica 7.1 (2005).

The FL was higher for fish fed the diet containing $1 \%$ inclusion of PHPPL compared to both the negative control (NC) and the positive control (PC). No significant differences were found for the other parameters, such as WG, SGR, PER, AFC, SV, and HIS $(P>0.05)$ (Table 3). Severe hepatic vacuolization was observed in the negative control and the $4 \%$ inclusion diet. The analysis of the hepatic tissue demonstrated cell alterations, with fat depositions and vacuolization being observed. All evaluated diets resulted in alterations; however, the diets $\mathrm{NC}$ and the ones with inclusions above $3 \%$ demonstrated to be prejudicial for the liver, leading to severe vacuolization (Table 4, Fig. $1)$.

The maintenance of the zootechnical performance attributes a positive aspect for the preference of PHPPL inclusion, upon the use of fishmeal. Lewandowski et al. (2014) evaluated swine liver hydrolysates in diets for jundiá (Rhamdia voulezi) and mandi (Pimelodus britski) larvae and did not observe prejudices in performance parameters. In this study, the observed values of SV were positive, seen that de diets containing PHPPL did not affect this parameter, which 

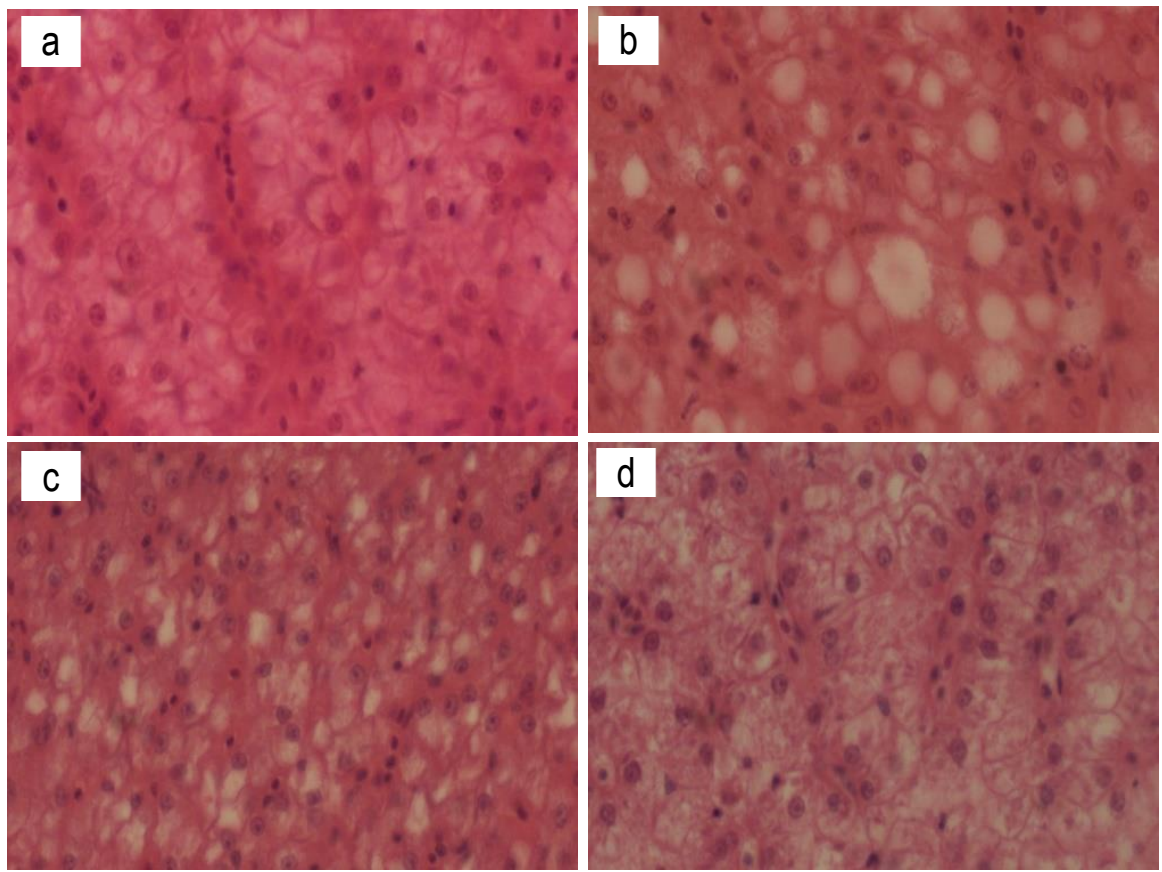

Figure 1. Photomicrography of liver of Nile tilapia (Oreochromis niloticus) with hepatocytes vacuolization in different degrees of severity (HE 40x). a) Defined hepatocyte cell limit and well-marked nucleus (score $=0$ ), b) presence of small intracellular vacuoles, without shape alteration, and positioning of hepatocyte nucleus (score $=1$ ), c) hepatocytes with apparent and large vacuoles (score $=2$ ), d) severe vacuolization of the cytoplasm, loss of cellular shape and presence of periphery nucleus (score $=3$ ).

Table 3. Mean values of performance and proximate composition of Nile tilapia (Oreochromis niloticus) fed diets containing different inclusion levels of PHPP (protein hydrolysate of poultry by-products and swine liver). According to Tukey's test, means followed by distinct letters within the same line represent a significant difference $(P<0.05) .{ }^{1} \mathrm{NC}$ : negative control (without PHPPL and fishmeal), ${ }^{2} \mathrm{PC}$ : positive control (without PHPPL, with fishmeal). MIW: mean initial weight, WG: weight gain, FL: final length, SGR: specific growth rate, PER: protein efficiency rate, AFC: apparent feed conversion, SV: survival, HIS: hepatosomatic index.

\begin{tabular}{lccccccc}
\hline \multirow{2}{*}{ Variable } & \multicolumn{7}{c}{ Inclusion levels of the protein hydrolysate of poultry byproducts and swine liver (\%) } \\
\cline { 2 - 8 } & $\mathrm{NC}^{1}$ & \multicolumn{7}{c}{$\mathrm{PC}^{2}$} & \multicolumn{1}{c}{$\%$} & \multicolumn{2}{c}{$2 \%$} & $3 \%$ & $4 \%$ \\
\hline Performance & & & & & & \\
MIW (g) & $1.42 \pm 0.01$ & $1.42 \pm 0.04$ & $1.44 \pm 0.01$ & $43 \pm 0.03$ & $1.42 \pm 0.04$ & $1.41 \pm 0.04$ & $1.39 \pm 0.02$ \\
WG (g) & $15.19 \pm 1.20$ & $15.30 \pm 0.35$ & $17.03 \pm 1.49$ & $15.83 \pm 1.25$ & $16.20 \pm 1.04$ & $15.29 \pm 1.42$ & $16.05 \pm 1.02$ \\
FL (cm) & $8.94 \pm 0.22 \mathrm{~b}$ & $9.04 \pm 0.11 \mathrm{~b}$ & $9.59 \pm 0.30 \mathrm{a}$ & $9.34 \pm 0.12 \mathrm{ab}$ & $9.16 \pm 0.27 \mathrm{ab}$ & $9.37 \pm 0.12 \mathrm{ab}$ & $9.21 \pm 0.12 \mathrm{ab}$ \\
SGR (\%) & $8.77 \pm 0.24$ & $8.79 \pm 0.04$ & $9.08 \pm 0.26$ & $8.88 \pm 0.22$ & $8.98 \pm 0.16$ & $8.80 \pm 0.36$ & $9.00 \pm 0.25$ \\
PER (\%) & $2.66 \pm 0.38$ & $2.90 \pm 0.12$ & $2.85 \pm 0.23$ & $2.88 \pm 0.25$ & $2.58 \pm 0.31$ & $2.70 \pm 0.21$ & $2.67 \pm 0.25$ \\
AFC & $1.03 \pm 0.14$ & $0.94 \pm 0.04$ & $0.95 \pm 0.04$ & $0.93 \pm 0.08$ & $1.05 \pm 0.14$ & $1.00 \pm 0.07$ & $1.04 \pm 0.10$ \\
SV (\%) & $87.50 \pm 10.75$ & $88.88 \pm 9.62$ & $100 \pm 0.00$ & $97.91 \pm 4.16$ & $87.50 \pm 15.95$ & $97.22 \pm 4.81$ & $91.66 \pm 11.78$ \\
HIS (\%) & $2.60 \pm 0.18$ & $2.26 \pm 0.19$ & $2.28 \pm 0.72$ & $2.40 \pm 0.27$ & $2.58 \pm 0.31$ & $2.32 \pm 0.12$ & $2.47 \pm 0.40$ \\
\hline
\end{tabular}

is an important parameter to be evaluated in experiments considering new feed ingredients (Santos et al., 2019).

Another relevant aspect regards the composition of the peptide fragments, as the PHPPL used in this study was composed of $8.88 \%$ peptides of $<250 \mathrm{Da}, 31 \%$ between 250-500 Da, and 60\% between 500-1000 Da. Aksnes et al. (2006) demonstrated that low concen- trations of peptides <100 Da have influenced in the productive performance of Gadus morhua due to reduced feed efficiency, while higher concentrations of small-size peptides are essential for fish's growth and nutrients use. Therefore, it is possible that the size and composition of PHPPL fragments did not contribute to the improvement of growth parameters, and there is a need for a balance of peptide size and sufficient amounts in order to influence growth performance. 
Table 4. Vacuolization score: 0: unobserved, 1: low vacuolization, 2: mean vacuolization, 3: severe vacuolization.

\begin{tabular}{lccccccc}
\hline \multicolumn{7}{c}{ Inclusion levels of protein hydrolysate of poultry byproducts and swine liver (PHPPL) (\%) } \\
\hline Variables & $\mathrm{NC}^{1}$ & $\mathrm{PC}^{2}$ & $1 \%$ & $2 \%$ & $3 \%$ & $4 \%$ & $5 \%$ \\
\hline V. score & $1-3$ & $0-1$ & $0-2$ & $0-2$ & $0-2$ & $0-3$ & $0-2$ \\
\hline
\end{tabular}

Nutrition is closely related to the liver, which may change its function and morphology. The appearance of hepatic steatosis is closely related to nutritional disturbances, especially regarding fatty acids imbalance (Tacon, 1996; Caballero et al., 2004). As demonstrated by Bombardelli et al. (2009) and Tessaro et al. (2014), there is a close relationship between increased energy levels and hepatic steatosis. Liland $e t$ al. (2015) obtained similar results with inclusions of byproducts (poultry, poultry grease, and swine blood meal) for Atlantic salmon (Salmo salar L.), showing that the diets containing such ingredients led to small and moderate lesions, while diets without hydrolysates similar to a commercial feed (with high plant-based ingredients), presented moderate to severe lesions. In this sense, it can be considered that the diets with up to $3 \%$ inclusion of PHPPL displayed an adequate balance of fatty acids (similar to the diet containing fishmeal), as it was possible to observe less vacuolization in the liver.

The PHPPL did not cause issues regarding its use as a feed ingredient for Nile tilapia juveniles in terms of zootechnical performance, and the inclusion level of $1 \%$ contributed to the final length of fish, while a $3 \%$ inclusion did not lead to liver alterations. Therefore, this inclusion level can be efficiently used in diets for Nile tilapia juveniles to replace fishmeal.

\section{ACKNOWLEDGMENTS}

The authors thank the company Brasil Foods S/A (sector $\mathrm{BRF}^{\circledR}$ Ingredients) for the financial support and CNPq (Conselho Nacional de Desenvolvimento Científico e Tecnológico) for the scholarship provided to the first author and CAPES (Coordenação de Aperfeiçoamento de Pessoal de Nível Superior) for to the second author.

\section{REFERENCES}

Aksnes, A., Hope, B., Høstmark, Ø. \& Albrektsen, S. 2006. Inclusion of size-fractionated fish hydrolysate in high plant protein diets for Atlantic cod, Gadus morhua. Aquaculture, 261(3): 1102-1110.
Alves, D.R.S., Silva, T.C., Rocha, J.D.M., Oliveira, S.R., Signor, A. \& Boscolo, W.R. 2019. Compelling palatability of protein hydrolysates for Nile tilapia juveniles. Latin American Journal of Aquatic Research, 47(2): 371-376.

Association of Official Analytical Chemists (AOAC). 2000. Official methods of analysis of Official Analytical Chemists. AOAC, Arlington.

Bombardelli, R.A., Hayashu, C., Natali, M.R.M., Sanches, E.A. \& Piana, P.A. 2009. Desempenho reprodutivo e zootécnico e deposição de lipídios nos hepatócitos de fêmeas de tilapia-do-nilo alimentadas com rações de diversos níveis energéticos. Revista Brasileira de Zootecnia, 38(8): 1391-1399.

Caballero, M.J., Izquierdo, M.S., Kjøsvik, E., Fernández, A.J. \& Rosenlund, G. 2004. Histological alterations in the liver of sea bream, Sparus aurata L. caused by short-or long-term feeding with vegetable oils. Recovery of normal morphology after feeding fish oil as the sole lipid source. Journal of Fish Diseases, 27(9): 531-541.

Food and Agriculture Organization (FAO). 2018. World fisheries and aquaculture: meeting sustainable development goals. Food and Agriculture Organization, Rome.

Furuya, W. 2010 Tabelas brasileiras para a nutrição de tilápias. GFM Gráfica e Editora Ltda., Toledo.

Lewandowski, L., Decarli, J.A., Pedron, F.A., Signor, A. \& Boscolo, W.R. 2013. Hidrolisados cárneos na alimentação do surubim do Iguaçu (Steindachneridion melanodermatum). Revista Brasileira de Ciência Veterinária, 20(4): 222-226.

Lewandowski, L., Sary, C., Schuller, J.M., Dieterich, F., Feiden, A., Signor, A. \& Boscolo, W.R. 2014. Hidrolisados proteicos em dietas para larvas de peixes. Revista Acadêmica: Ciências Agrárias e Ambientais, 12(4): 277-282.

Liland, N.S., Hatlen, H., Venegas, C., Espe, M., Tortensen, B.E. \& Waagb $\varnothing$, R. 2015. Including processed poultry, and porcine byproducts in diets high in plant ingredients reduced liver TAG in Atlantic salmon, Salmon salar L. Aquaculture Nutrition, 21(5): 655-669. 
Lorenz, E.K., Barone, R.S.C., França, W.G., Sabioni, R.E., Koch, J.F.A. \& Cyrino, J.E.P. 2018. Performance, hematology, and immunology of Salminus brasiliensis fed diets containing swine liver hydrolysate. Aquaculture, 483: 46-52.

Martínez-Alvarez, O., Chamorro, S. \& Brenes, A. 2015. Protein hydrolysates from animal processing byproducts as a source of bioactive molecules with interest in animal feeding: a review. Food Research International, 73: 204-212.

Received: 10 March 2020; Accepted: 8 July 2020
National Research Council (NRC). 2011. Nutrient requirements of fishes and shrimp. National Academies Press, Washington.

Santos, L.D., Zadinelo, I.V., Moesch, A., Bombardelli, R.A. \& Meurer, F. 2019. Crude glycerol in diets for Nile tilapia in the fattening stage. Pesquisa Agropecuária Brasileira, 54: e00460.

Tacon, A.G.J. 1996. Lipid nutritional pathology in farmed fish. Archives of Animal Nutrition, 44(1): 33-39.

Tessaro, L. Toledo, C.P.R., Neumann, G., Krause, R.A., Meurer, F., Natali, M.R.M. \& Bombardelli, R.A. 2014. Animal performance and reproductive aspects of female Rhamdia quelen fed on different levels of digestible energy. Aquaculture Research, 45(9): 14251433. 